\title{
How to deliver information on induced seismicity to the authorities and general public?
}

\section{Junno, Niina}

2021

Junno , N , Bäcklund , P , Tuomisaari , J M , Oinonen , K, Veikkolainen , T \& Korja , A 2021

, How to deliver information on induced seismicity to the authorities and general public? in Geophysical Research Abstracts ., EGU21-2732 , EGU General assembly 2021, 19/04/2021 . https://doi.org/10.5194/egusphere-egu21-2732

http://hdl.handle.net/10138/332249

https://doi.org/10.5194/egusphere-egu21-2732

cc_by

publishedVersion

Downloaded from Helda, University of Helsinki institutional repository.

This is an electronic reprint of the original article.

This reprint may differ from the original in pagination and typographic detail.

Please cite the original version. 


\section{EGU21-2732}

https://doi.org/10.5194/egusphere-egu21-2732

EGU General Assembly 2021

(c) Author(s) 2021. This work is distributed under

the Creative Commons Attribution 4.0 License.

\section{How to deliver information on induced seismicity to the authorities and general public?}

Niina Junno, Pia Bäcklund, Johanna Tuomisaari, Kati Oinonen, Toni Veikkolainen, Annakaisa Korja, and Seismic Risk Working Group

Department of Geosciences and Geography, University of Helsinki, Finland (niina.junno@helsinki.fi)

Alternative, carbon-free energy sources are essential to regulate the global climate crisis. Geothermal energy - i.e., heat harvested by geothermal systems by drilling geothermal wells to circulate water in a fractured hot rock mass at the depth of 1-7 km - has a huge potential as an environmentally friendly carbon-free energy source. One of the drawbacks is that geothermal systems can induce small-magnitude earthquakes that pose seismic risk to critical sensitive infrastructure. SEISMIC RISK - Mitigation of induced seismic risk in urban environments -project focuses on how to evaluate, mitigate and communicate seismic hazard and risk in an urban environment. Some of the associated challenges are the unclear regulatory, administrative and policy processes and unclear roles of the different actors. Another problem concerns defining what constitutes relevant information and how it should be disseminated to the public.

One part of the project is to carry out interviews of stakeholders (energy companies, municipalities and state authorities) on, how they perceive the current situation. These will give information on 1) the extent to which different actors have a common understanding of the situation and potential risks, 2) who should be responsible for coordinating risk management, and 3) how citizens should be informed of potential risks and should they be able to participate in location decisions of such geothermal power plants. Another part of the project is focusing on, how social media can better be used for rapid communication of induced seismic events and for the gathering of observations. Currently social media (Twitter) is already used for rapid notification of seismic events to the public. Gathering of macroseismic observations is handled online. 